\title{
Acacia plantation in different quality sites and fertilization in Northeast Vietnam
}

Tran Van Do*

Silviculture Research Institute, Vietnamese Academy of Forest Sciences, Hanoi, Vietnam

\begin{abstract}
Received:
December 07, 2019

Accepted:

March 03, 2020

Published:

July 30, 2020

Abstract

The impacts of site quality and fertilization on the growths of acacia plantation have become important in plantation management. It could provide information on which site and how much fertilizer should be applied, contributing to sustainable plantation management. In this study, two sites of different conditions of soil depths (30-40 $\mathrm{cm} /$ shallow soil site and $70-80 \mathrm{~cm} /$ deep soil site) and of rock contents $(<10 \%$ and $>$ 45\%); and fertilizing $200 \mathrm{~g}$ NPK (16:16:8)/tree/year and control (non-fertilization) were experimented in an Acacia mangium plantation in northeast Vietnam. The plantation was established in September 2017, fertilizer was applied in Junes 2018 and 2019. Site conditions and fertilization significantly affected the growths of 2-year-old plantation. In shallow soil site, the plantation in fertilization treatment achieved $498 \%$ basal area and 595\% aboveground biomass of plantation in non-fertilization treatment. The difference among control and fertilizing $200 \mathrm{~g}$ NPK/tree in deep soil site, and fertilizing $200 \mathrm{~g} \mathrm{NPK} /$ tree in shallow soil site was not significant. It is concluded that fertilizing NPK to acacia plantation in the present study site is necessary for shallow soil site even trees become older, while in deep soil site fertilization is required only in the first year to support initial growths.
\end{abstract}

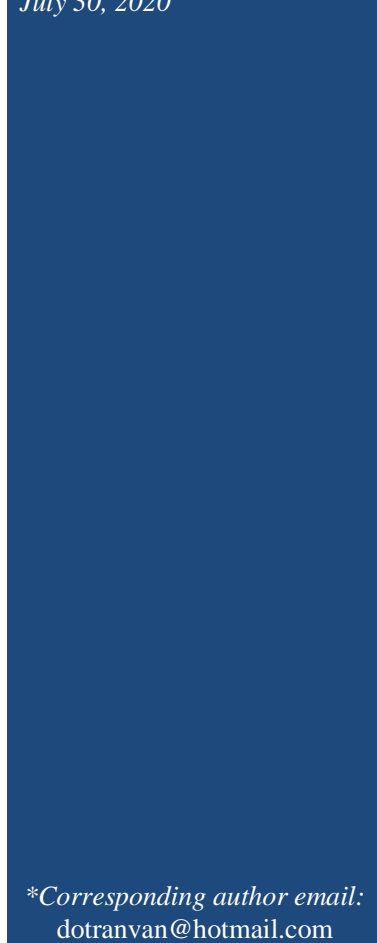

Keywords: Fertilization, Plantation growth, Shallow soil, Site condition, Soil nutrient pool

\section{How to cite this:}

Tran VD, 2020. Acacia plantation in different quality sites and fertilization in Northeast Vietnam. Asian J. Agric. Biol. 8(3): 240-246. DOI: https://doi.org/10.35495/ajab.2019.12.554

This is an Open Access article distributed under the terms of the Creative Commons Attribution 3.0 License. (https://creativecommons.org/licenses/by/3.0), which permits unrestricted use, distribution, and reproduction in any medium, provided the original work is properly cited.

\section{Introduction}

Fertilization has been widely applied in many species around the world to increase forest plantation productivity (Shi et al., 2019; Hung et al., 2009), and it is a viable silvicultural option for sustainable plantation management (Fox et al., 2007). Site quality has the greatest and often longest-lasting effect on the productivity of plantations. Fertilization on high fertile sites often has little effect, while that on low fertile sites can have remarkably positive effects. The macronutrients (Sulaiman et al., 1990) including Nitrogen $(\mathrm{N})$, Phosphorus $(\mathrm{P})$, and Potassium (K) are the key limiting nutrients in many sites (Goncalves et al., 2007). Fertilizers could be applied at and/or after planting annually to support tree's growths ( $\mathrm{Vu}$ et al., 2019; Tran et al., 2018; Tran et al., 2017; Guo et al., 2016; Lamani et al., 2004). The main purpose of 
fertilization to any plantation is to supply nutrients to planted trees for better growths and higher survival rate (Earnshaw et al., 2016; Forrester et al., 2012). Therefore, growers expect that planted trees can absorb as much applied fertilizer as possible (Silva et al., 2013).

Fertilization at planting, which creates favorable soil chemical properties for root establishment, is considered to play an important role in the survival and early growth of the plantation. Plants with poorly developed root systems require high nutrients in the planting establishment stage. Therefore in low and medium natural fertility soil, forest productivity increases considerably by early fertilization (Goncalves and Barros, 1999). Maintenance fertilization is carried out after plantation establishment when soil nutrient does not meet plants' nutrient demand. Fertilizer is applied one a year, but usually only before canopy closure. This stage is characterized by a rapid increase of plantation biomass with the highest increment in leaf area index to promote photosynthesis (Viera et al., 2015; Goncalves et al., 2004). The main purpose of maintenance fertilization is to provide necessary amounts of fertilizers that can mismatch between plant's demand and edaphic supply.

Management of soil fertility and plant nutrition is important for increasing plantation productivity (Smethurst, 2000; 2010; Pinkard, 2003). In areas of low natural fertility, low production may be caused by inadequate plant nutrition, and therefore fertilization becomes necessary. The type and quantity of fertilizers to be applied depend on a number of factors such as nutritional demands of the species (Tran, 2019), the natural soil fertility, soil chemical, and physical characteristics, soil-fertilizer reaction, fertilization efficiency, and site hydric availability (Ryan et al., 2010; Smethurst, 2010). However, the plant nutrient demands should be balanced with the provision of nutrients in time and space. Soil nutrient balance and yield classes (Barros et al., 1992) and critical soil nutrient levels (Goncalves et al., 2008) are important tools for determining fertilizer needs.

Plantation has been contributing significantly to the rural economy in many tropical regions (FAO, 1981). Acacia plantations are becoming increasingly important to the national economy and contributing to livelihood of million people in rural areas, Vietnam (Kien et al., 2014). The objective of this study is to examine the effect of fertilization in different quality sites on Acacia mangium plantation in northeast Vietnam.

\section{Material and Methods}

\section{Study site}

The study was conducted in northeast Vietnam at $21^{\circ} 4^{\prime} 14.2^{\prime \prime} \mathrm{N}$ and $107^{\circ} 2^{\prime} 52.6^{\prime \prime} \mathrm{E}$. The site belongs to the monsoon climate region with the average annual temperature of $22.2^{\circ} \mathrm{C}$ and air humidity of $81 \%$ (QCVN02, 2009). The area has an annual precipitation of 1600-2200 mm. The soil in the site is classified as Ferralic Acrisol. There are two microsites, which is 30 $\mathrm{m}$ far away from each other by a narrow canyon. The quality of microsites is indicated in Table 1.

Table-1: Quality of two microsites for the experiment

\begin{tabular}{|c|l|c|c|}
\hline No & \multicolumn{1}{|c|}{ Characteristic } & \multicolumn{1}{|c|}{ Site A } & Site B \\
1 & \multicolumn{1}{|c|}{ Initial vegetation } & $\begin{array}{l}\text { Some trees of Acacia mangium } \\
\text { and Eucalyptus urophylla, and } \\
\text { other shrubs (shorter than 3 m) }\end{array}$ \\
\hline 2 & Soil depth $(\mathrm{cm})$ & $70-80$ & $30-40$ \\
\hline 3 & Rock content $(\%)$ & $<10$ & $>45$ \\
\hline 4 & Sand $(0.02-2 \mathrm{~mm})(\%)$ & 56.77 & 56.06 \\
\hline 5 & $\begin{array}{l}\text { Loam }(0.002-0.02 \\
\text { mm }(\%)\end{array}$ & 23.53 & 25.93 \\
\hline 6 & Silt $(<0.002 \mathrm{~mm})(\%)$ & 19.70 & 18.01 \\
\hline 7 & $\mathrm{pH}$ & 3.92 & 3.89 \\
\hline 8 & $\mathrm{~N}(\%)$ & 0.07 & 0.07 \\
\hline 9 & $\mathrm{P}_{2} \mathrm{O}_{5}(\mathrm{mg} / 100 \mathrm{~g})$ & 0.34 & 0.33 \\
\hline 10 & $\mathrm{~K}_{2} \mathrm{O}(\mathrm{mg} / 100 \mathrm{~g})$ & 5.22 & 4.34 \\
\hline
\end{tabular}

\section{Experimental design}

The experiment included two sites (Table 1), including microsite A known as deep soil site and microsite B known as shallow soil site.

Fertilization experiment included two treatments, including (a) fertilizing $200 \mathrm{~g}$ NPK (16:18:8)/tree and control (non-fertilization). Fertilizer was applied at planting and in the first and the second year after planting with the same amount of $200 \mathrm{~g}$ NPK/tree/time.

Four-month-old $A$. mangium seedlings with a stump diameter (diameter measured at collar root) of 3.5-3.7 $\mathrm{mm}$ and a height of $0.55-0.57 \mathrm{~m}$ were used. Planting pit with sizes of $30 \times 30 \times 30 \mathrm{~cm}$ was prepared. Trees were planted in September 2017. Maintenance fertilization was conducted in Junes 2018 and 2019. A pit of $10 \mathrm{~cm}$ width $\times 10 \mathrm{~cm}$ length $\times 15 \mathrm{~cm}$ depth near a stump of A. mangium tree was made, and fertilizer was inserted and then covered with fine soil. Vegetation near the pit was cleared. 
The experiments were conducted in two randomly completed blocks, one for microsite A and other for microsite B. Three replications were employed, leading to 6 subplots in each block. Each subplot contains 36 trees planted in $3 \mathrm{~m} \times 3 \mathrm{~m}$ spacing. The distance between subplots is $6 \mathrm{~m}$, which ensures no cross-interference among subplots.

\section{Data collection and aboveground biomass estimation}

Stem diameter at breast height $(\mathrm{DBH})$, stem height, and stem crown diameter $\left(D_{c}\right)$ were measured in September 2018 and October 2019. Then, aboveground biomass (AGB) of each stem was estimated based on DBH by applying allometry in Eq. 1 (Thanh and Thu, 2015). AGB of each replication was the total biomass of all stems in a subplot.

$\mathrm{AGB}=0.223 * \mathrm{DBH}^{2.251} \quad$ (1).

\section{Statistical analysis}

Growth parameters are reported as mean and standard error (SE). AGB is reported as the mean of three replications (subplots) with SE. While a comparison of growth parameters and AGB between microsites and fertilizations is reported as percentage.

Pair-comparison was employed to identify the effect of microsites and fertilization on growths and AGB of the plantation. All analyses were applied at $p=0.05$ using SAS 9.2 (SAS Institute Inc., Cary, NC, USA).

\section{Results}

Site and fertilization significantly affected the growth of 1- and 2-year-old A. mangium plantations (Table 2). For 1-year-old plantation in each site, fertilization had higher growths than that in control. Comparing between two sites in control indicated significant better growths in site A than that in site B. However, the difference between two sites in fertilizing $200 \mathrm{~g}$ NPK was not significant for both DBH and stem height. Meanwhile, for 2-year-old plantation, the difference of DBH among control and $200 \mathrm{~g}$ NPK in site A and $200 \mathrm{~g} \mathrm{NPK}$ at site B was not significant (Table 2), which was significantly higher than DBH in control at site B.
Table-2: Growths (mean \pm SE) of 1- and 2-year-old Acacia mangium plantations in different sites and fertilization

\begin{tabular}{|c|c|c|c|c|}
\hline & \multicolumn{2}{|c|}{ Site A } & \multicolumn{2}{c|}{ Site B } \\
\hline & Control & $\mathbf{2 0 0}$ g NPK & Control & $\mathbf{2 0 0}$ g NPK \\
\hline \multicolumn{4}{|c|}{ 1-year-old plantation (data measured in September 2018) } \\
\hline $\begin{array}{c}\text { DBH } \\
(\mathrm{cm})\end{array}$ & $3.54 \pm 0.26^{\mathrm{a}}$ & $4.75 \pm 0.13^{\mathrm{b}}$ & $1.24 \pm 0.17^{\mathrm{c}}$ & $4.94 \pm 0.17^{\mathrm{b}}$ \\
\hline $\begin{array}{c}\text { Height } \\
(\mathrm{m})\end{array}$ & $2.92 \pm 0.10^{\mathrm{a}}$ & $3.77 \pm 0.07^{\mathrm{b}}$ & $2.05 \pm 0.11^{\mathrm{c}}$ & $3.98 \pm 0.10^{\mathrm{b}}$ \\
\hline \multicolumn{5}{|c|}{$2-$ year-old plantation (data measured in October 2019$)$} \\
\hline $\begin{array}{c}\text { DBH } \\
(\mathrm{cm})\end{array}$ & $8.68 \pm 0.59^{\mathrm{a}}$ & $9.46 \pm 0.29^{\mathrm{a}}$ & $3.52 \pm 0.57^{\mathrm{b}}$ & $\begin{array}{c}10.09 \\
\pm 0.29^{\mathrm{a}}\end{array}$ \\
\hline $\begin{array}{c}\text { Height } \\
(\mathrm{m})\end{array}$ & $6.87 \pm 0.17^{\mathrm{a}}$ & $6.97 \pm 0.14^{\mathrm{a}}$ & $3.76 \pm 0.34^{\mathrm{b}}$ & $7.83 \pm 0.14^{\mathrm{c}}$ \\
\hline $\mathrm{D}_{\mathrm{c}}(\mathrm{m})$ & $3.70 \pm 0.21^{\mathrm{a}}$ & $4.19 \pm 0.11^{\mathrm{a}}$ & $1.48 \pm 0.31^{\mathrm{b}}$ & $4.77 \pm 0.10^{\mathrm{c}}$ \\
\hline
\end{tabular}

Different letters ${ }^{a, b, c}$ in a line indicate significant difference of means at $p=0.05$


Fig-1: Basal area and aboveground biomass (AGB) of 1-year-old Acacia mangium plantation in different sites and fertilization. Different letters ${ }^{a, b}$, c indicate significant difference of means at $\boldsymbol{p}=0.05$. Bars indicate $+\mathrm{SE}$ 
The pattern of difference of height and crown diameter between sites and fertilization was similar. The best belonged to $200 \mathrm{~g}$ NPK at site B, reduced to control and $200 \mathrm{~g} \mathrm{NPK}$ at site A, and the lowest belonged to control at site B. The difference of height and crown diameter between control and $200 \mathrm{~g} \mathrm{NPK}$ at site A was not significant (Table 2). Basal area and AGB were significantly different between sites and fertilization in 1-year-old plantation (Fig. 1). The highest belonged to $200 \mathrm{~g}$ NPK at both sites, reduced to control at site A, and the lowest belonged to control at site B. A 1-yearold plantation achieved basal area of $2.17 \mathrm{~m}^{2} \mathrm{ha}^{-1}$ at site $\mathrm{B}$ and $2.01 \mathrm{~m}^{2} \mathrm{ha}^{-1}$ at site A in fertilizing $200 \mathrm{~g}$ NPK, $1.18 \mathrm{~m}^{2} \mathrm{ha}^{-1}$ in control at site A, and $0.17 \mathrm{~m}^{2}$ ha ${ }^{1}$ in control at site B. It achieved AGB of 8.96 tons ha ${ }^{1}$ at site $\mathrm{B}$ and 8.53 tons $\mathrm{ha}^{-1}$ at site $\mathrm{A}$ in fertilizing 200 g NPK, 4.76 tons ha ${ }^{-1}$ in control at site $\mathrm{A}$, and 0.57 tons ha $^{-1}$ in control at site B (Fig. 1).
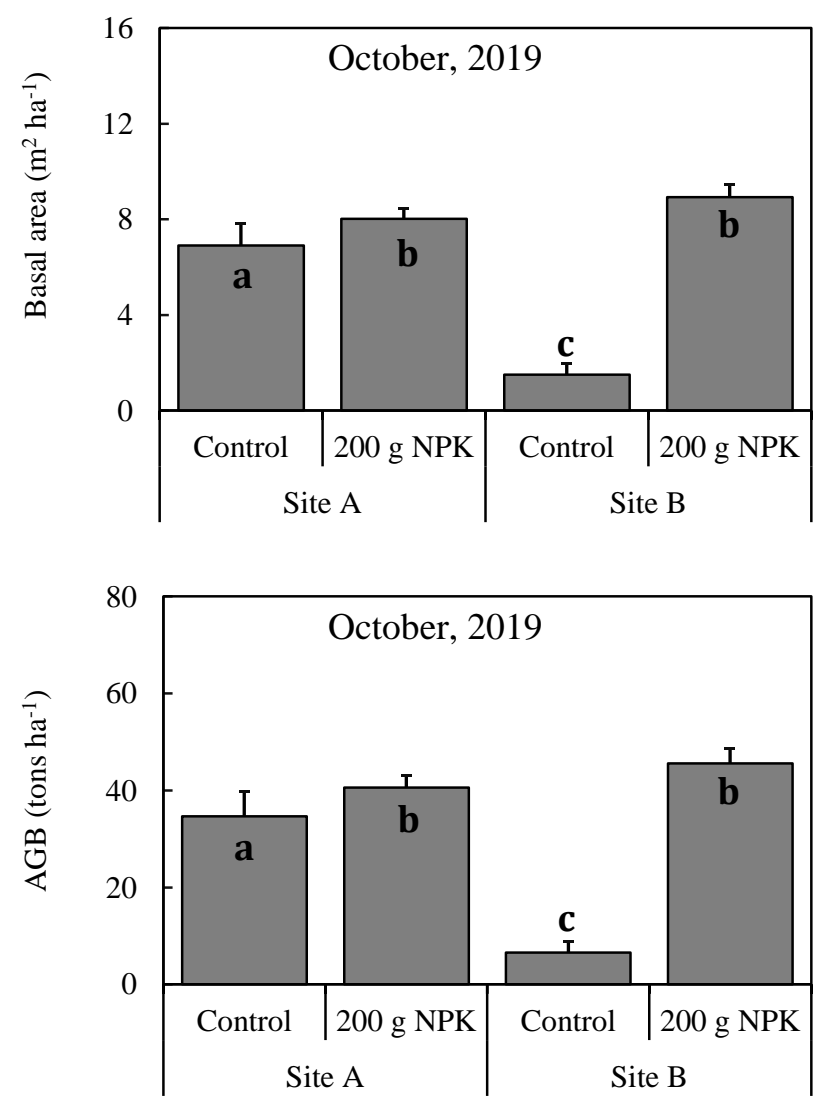

Fig-2: Basal area and aboveground biomass (AGB) of 2-year-old Acacia mangium plantation in different sites and fertilization. Different letters a, $b, c$ indicate significant difference of means at $p$ $=0.05$. Bars indicate $+\mathrm{SE}$
Basal area and AGB were significantly different between sites and fertilization in 2-year-old plantation (Fig. 2). The highest belonged to $200 \mathrm{~g} \mathrm{NPK}$ at both sites, reduced to control at site $\mathrm{A}$, and the lowest belonged to control at site B. A 2-year-old plantation achieved basal area of $8.92 \mathrm{~m}^{2} \mathrm{ha}^{-1}$ at site $\mathrm{B}$ and 8.02 $\mathrm{m}^{2} \mathrm{ha}^{-1}$ at site A in fertilizing $200 \mathrm{~g}$ NPK, $6.91 \mathrm{~m}^{2} \mathrm{ha}^{-1}$ in control at site A, and $1.49 \mathrm{~m}^{2} \mathrm{ha}^{-1}$ in control at site B. It achieved AGB of 45.55 tons $\mathrm{ha}^{-1}$ at site $\mathrm{B}$ and 40.60 tons $\mathrm{ha}^{-1}$ at site A in fertilizing $200 \mathrm{~g} \mathrm{NPK}, 34.68$ tons $\mathrm{ha}^{-1}$ in control at site $\mathrm{A}$, and 6.55 tons $\mathrm{ha}^{-1}$ in control at site $\mathrm{B}$.

Comparing to control at site B (Fig. 3), plantations in $200 \mathrm{~g} \mathrm{NPK}$ at site B, and control and $200 \mathrm{~g} \mathrm{NPK}$ at site $A$ had much higher ratios of basal area and AGB. Basal area increased 360-500\%, while AGB increased $430-600 \%$.

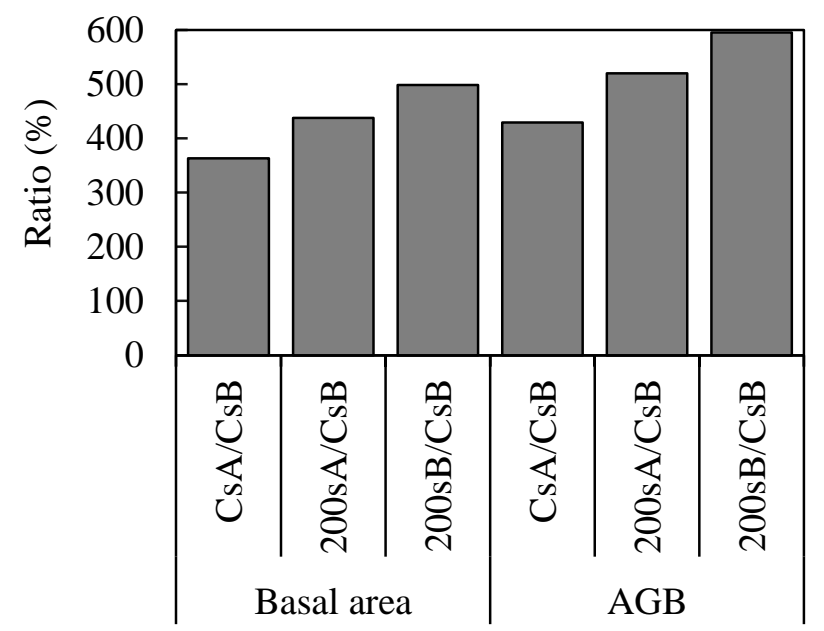

Fig-3: Comparisons of basal area and aboveground biomass (AGB) of 2-year-old Acacia mangium plantation between treatments. CsA/CsB is between control at site $A$ and control at site $B$; 200sA/CsB is between $200 \mathrm{~g}$ NPK at site $A$ and control at site $B ; 200 \mathrm{sB} / \mathrm{CsB}$ is between $200 \mathrm{~g} \mathrm{NPK}$ at site $B$ and control at site $B$

\section{Discussion}

$\mathrm{N}$ and $\mathrm{P}$ contents in soil are not different between two sites (Table 1), while $\mathrm{K}$ content in site $\mathrm{A}$ is higher than that in site B. Other soil characteristics are also not different, accept soil depth and rock content; soil is shallower and rock is more numerous in site B. Such characteristics indicated that total nutrient pool in site $\mathrm{A}$ is much higher than that in site $\mathrm{B}$. It is indicated that 
legumes require higher $\mathrm{P}$ and lower $\mathrm{N}$ than nonlegumes, as they can fix nitrogen themselves (Inagaki et al., 2009). Meanwhile, there has not recorded the importance of $\mathrm{K}$ in the growths of acacia trees. Therefore, $\mathrm{P}$ could be limited nutrient in the present study site and $\mathrm{P}$ application becomes important for acacia plantation (Vu et al., 2019).

Control in site B with a low total nutrient pool had the lowest growths, basal area, and AGB (Table 2, Fig. 1 and 2). The gaps of difference in the 2-year-old plantation were even much higher than that in the 1year-old plantation. This again indicated the importance of total nutrient pool in the soil for tree growths when they are getting older (Chi et al., 2015; Mohren and De Veen, 1995). Meanwhile, in the 2year-old plantation, the difference of growths between control and $200 \mathrm{~g}$ NPK at site A (Table 1) was not significant, indicating the unnecessary of fertilization in the deep soil site with a high total nutrient pool. In older plantation, trees develop a good root system that is deeper and larger to acquire naturally available nutrients (Nicoll and Ray, 1996) in high total nutrient pool soil of site A meeting their nutrient demands. Conversely, in site B with shallow soil and high rock content, trees could not develop their root systems and there is low nutrient availability in nature. Therefore, they cannot grow well and fertilization becomes necessary.

The present study sites seem $\mathrm{K}$ rich but $\mathrm{P}$ poor. Therefore $\mathrm{K}$ fertilization is not necessary, while $\mathrm{P}$ fertilization becomes important ( $\mathrm{Vu}$ et al., 2019). Applying NPK in the present study may lead to a high loss rate of $\mathrm{K}$. Therefore, applying sole $\mathrm{P}$ fertilizer may bring more benefit to forest growers as it is cheaper than NPK fertilizer and can reduce the loss rate of applied fertilizer.

Fine roots (diameter $\leq 2 \mathrm{~mm}$ ) absorb water and nutrients for a tree's life (Nguyen et al., 2019). Fine roots usually distribute in the top and fertile soil layer, however, it can also be found deeper than $70 \mathrm{~cm}$ (Lai and Tran, 2019; Nguyen et al., 2019). Meanwhile, in site B there is a shallow soil layer of $<40 \mathrm{~cm}$ and a deeper layer is parent rock, which is hard and fine roots could not grow in. Therefore, nutrient deficiency becomes more serious in the site with a shallow soil layer (Nicoll and Ray, 1996). Leaching will bring nutrients to deeper soil layer and it could be taken up by fine roots in deeper oil, but it may not be a case in shallow soil as site B. Therefore, fertilizing more amount of fertilizer in a time in shallow soil will lead to high loss rate by erosion, which washes away nutrients from the site and planted trees cannot absorb anymore compared to leaching. In shallow soil, fertilization should be conducted more times with a less amount in each time to ensure as much fertilizer uptake by planted trees as possible.

\section{Conclusion}

This study examined the effects of fertilization and site quality on the growths of Acacia mangium plantation in northeast Vietnam. The results indicated that fertilization is necessary for shallow and high rock content soil even when trees become older. While in deep and less rock soil, fertilization is required only in the first year to support initial growth. A 2-year-old plantation in deep (70-80 cm) and less rock content $(<$ $10 \%$ ) soil without fertilization can achieve $363 \%$ basal area and $429 \%$ AGB of plantation in shallow (30-40 $\mathrm{cm}$ ) and high rock content (> 40\%) soil. While in shallow and high rock content soil with fertilizing 200 g NPK/tree could achieve $498 \%$ basal area and 595\% AGB of plantation in the same site without fertilization.

Acacia mangium plantation in the present study may require only $\mathrm{P}$ other than $\mathrm{N}$ and $\mathrm{K}$. Therefore, a study on using sole $\mathrm{P}$ should be conducted to reduce the loss rate of $\mathrm{N}$ and $\mathrm{K}$ fertilizer and increase benefit for forest growers.

\section{Acknowledgment}

I would like to thank all colleagues for constructive comments on the manuscript.

Disclaimer: None.

Conflict of Interest: None.

Source of Funding: This research was funded by Vietnam National Foundation for Science and Technology Development (NAFOSTED) under grant No. 106-NN.06-2016.10.

\section{References}

Barros NF, Novais RF, Neves JCL and LeaL PGL, 1992. Fertilizing eucalypt plantations on the Brazilian savannah soils. South Afr. Forest. J. 160: 7-12.

Chi X, Tang Z, Xie Z, Guo Q, Zhang M, Ge J, Xiong $G$ and Fang J, 2015. Effects of size, neighbors, and site condition on tree growth in a subtropical 
evergreen and deciduous broad-leaved mixed forest, China. Ecol. Evol. 5: 5149-5161.

Earnshaw KM, Baribault TW and Jacobs DF, 2016. Alternative field fertilization techniques to promote restoration of leguminous Acacia koa on contrasting tropical sites. Forest. Ecol. Manage. 376: 126-134.

FAO, 1981. Map of the fuelwood situation in the developing countries. Unasylva 33, supplement.

Forrester DI, Collopy JJ, Beadle CL, Warren CR and Baker TG, 2012. Effect of thinning, pruning and nitrogen fertilizer application on transpiration, photosynthesis and water-use efficiency in a young Eucalyptus nitens plantation. Forest. Ecol. Manage. 266: 286-300.

Fox TR, Allen HL, Albaugh TJ, Rubilar R and Carlson CA, 2007. Tree nutrition and forest fertilization of pine plantations in the Southern United States. South. J. Appl. Forest. 31: 5-11.

Goncalves JLM and Barros NF, 1999. Improvement of site productivity for short-rotation plantations in Brazil. Bosque. 20: 89-106.

Goncalves JLM, Stape JL, Benedetti VAG, Fessel VAG and Gava JL, 2004. An evaluation of minimum an intensive soil preparation regarding fertility and tree nutrition. In Forest Nutrition and Fertilization; Goncalves JLM, Benedetti VAG (Eds.). IPEF: Piracicaba, Brazil. pp. 13-64.

Goncalves JLM, Stape JL, Laclau JP, Bouillet JP and Ranger J, 2008. Assessing the effects of early silvicultural management on long-term site productivity of fast growing Eucalypt plantations: The Brazilian experience. South Afr. J. Sci. 70: 105-118.

Goncalves JLM, Wichert MCP, Gava JL, Masetto AV, Arthur JCJ, Serrano and Mello SLM, 2007. Soil fertility and growth of Eucalyptus grandis in Brazil under different residue management practices. South. Hemisph. Forest. J. 69: 95-102.

Guo J, Wu Y, Wang B, Lu Y, Cao F and Wang G, 2016. The effects of fertilization on the growth and physiological characteristics of Ginkgo biloba L. Forests. 7: 293.

Hung TT, Almeida AC, Eyles A, Ratkowsky D, Lam VT and Mohammed C, 2009. Maximizing growth and sawlog production from Acacia hybrid plantations in Vietnam. New Forest. 50: 785-804.

Inagaki M, Inagaki Y, Kamo K and Titin J, 2009. Fineroot production in response to nutrient application at three forest plantations in Sabah, Malaysia: higher nitrogen and phosphorus demand by Acacia mangium. J. Forest. Res. 14: 178-182.

Kien ND, Thinh HH, Kha LD, Nghia NH, Hai PH and Hung TV, 2014. Acacia as a national resource of Vietnam. In: 'Sustaining the Future of Acacia Plantation Forestry' International Conference, IUFRO Working Party 2.08.07: Genetics and Silviculture of Acacia, Hue, Vietnam, 18-21 March 2014, Compendium of Abstracts.

Lai TH and Tran VD, 2019 Fineroot dynamics and production in Acacia auriculiformis plantation. Plant Cell Biotech. Mol. Biol. 20: 604-610.

Lamani VK, Patil SK and Manjunath GO, 2004. Growth of Acacia auriculiformis as influenced by N, P and K fertilizers. Karnataka J. Agric. Sci. 17: 872-874.

Mohren GMJ and de Veen JR, 1995. Forest growth in relation to site conditions. Application of the model FORGRO to the Solling spruce site. Ecol. Modell. 83: 173-183.

Nguyen TT, Vu TL, Nguyen HS, Tran VD, Dang VT, Phung DT, Pham DS, Tran HQ, Nguyen TTP, Ly TTH, Nguyen HT, Nguyen VT, Dao TD, Dang THH, Duong QT, Ho TL and Nguyen THA, 2019. Changes in fineroot growth dynamics in response to phosphorus application in an Acacia mangium plantation in Vietnam. New Forest. doi: 10.1007/s11056-019-09763-4.

Nicoll B and Ray D, 1996. Adaptive growth of tree root systems in response to wind action and site condition. Tree Physiol. 16: 891-898.

Pinkard EA, 2003. Physiological and growth responses related to pattern and severity of pruning in young Eucalyptus globulus. Forest. Ecol. Manage. 182: 231-245.

QCVN02, 2009. Vietnam Building Code Natural Physical \& Climatic Data for Construction. Hanoi.

Ryan MG, Stape JL, Binkley D, Fonseca S, Loos RA, Takahashi EN, Silva CRR, Siva SR, Hakamada RE and Ferreira JM, 2010. Factors controlling Eucalyptus productivity: How water availability and stand structure alter production and carbon allocation. Forest. Ecol. Manage. 259: 16951703.

Shi W, Grossnickle SC, Shuchai GL and Liu SU, 2019. Fertilization and irrigation regimes influence on seedling attributes and field performance of Pinus tabuliformis Carr. Forestry. 92: 97-107.

Silva PHM, Poggiani F, Libardi PL and Gonçalves AN, 2013. Fertilizer management of eucalypt 
plantations on sandy soil in Brazil: Initial growth and nutrient cycling. Forest. Ecol. Manage. 301: 67-78.

Smethurst PJ, 2000. Soil solution and other soil analyses as indicators of nutrient supply: A review. Forest. Ecol. Manage. 138: 397-411.

Smethurst PJ, 2010. Forest fertilization: Trends in knowledge and practice compared to agriculture. Plant Soil. 335: 83-100.

Sulaiman A, Kadir QRA and Midon MS, 1990. Effects of fertilizer on wood properties of plantation crown Acacia mangium. J. Trop. Forest. Sci. 4: 119-126.

Thanh TX and Thu DH, 2015. Study on carbon accumulation capacity of the Acacia mangium plantation in Ngoc Thanh commune, Phuc Yen district, Vinh Phuc province, Vietnam. Proc. Natl. Sci. Conf. Ecol. Biol. Resour. 6: 1660-1666.

Tran VD, 2019. Nutrient contents in different organs of Acacia mangium, Northeast Vietnam. Plant Cell Biotech. Mol. Biol. 20: 521-527.
Tran VD, Dang VT and Nguyen TT, 2017. Effect of fertilization on growth of Eucalyptus urophylla plantation. J. App. Life Sci. Int. 11: 1-6.

Tran VD, Dang VT, Nguyen TT, Phung DT, Vu TL, Tran DM, Pham DS, Vu VT, Nguyen QH, Pham TD, Nguyen HT, Ninh VK, Tran HQ, Nguyen HH, Dinh HD, Tran AH, Duong QT, Hoang VT, Ho TL and Dao TD, 2018. Importance of fertilization on growth and biomass of acacia plantations in Vietnam. Asian J. Adv. Agric. Res. 6: $1-6$.

Viera M, Schumacher MV, Liberalesso E and Rodriguez-Soalleiro R, 2015. Mixed and monoespecific stands of eucalyptus and blackwattle. II-Fine root biomass density. Cerne. 21: 209-217.

Vu TL, Nguyen HS, Nguyen TT, Phung DT, Pham DS, Ho TL, Nguyen HT, Dao TD and Tran VD, 2019. Importance of phosphorus application in Acacia mangium plantation. World J. Adv. Res. Rev. 2: 7-12. 